\title{
Current and Voltage Harmonics Analysis in Green Building Case Study in Universitas Muhammadiyah Yogyakarta
}

\author{
Tony K. Hariadi ${ }^{* 1}$, Agus Jamal ${ }^{1}$, Nurohman Fadilah ${ }^{1}$, Faaris Mujaahid ${ }^{1}$ \\ ${ }^{1}$ Department of Electrical Engineering, Faculty of Engineering, Universitas Muhammadiyah Yogyakarta \\ Kampus Terpadu UMY, Jalan Brawijaya, Bantul, Yogyakarta, Indonesia \\ *Corresponding author, e-mail: tonykhariadi@umy.ac.id
}

\begin{abstract}
This paper described research to investigate Total Harmonic Distortion (THD) on a supposedly green building; Admission Building in Universitas Muhammadiyah Yogyakarta. Observation was done for seven days involving peak and non-peak hours including workdays and off days. Data sampling was recorded 24 hours with one-hour interval for primary parameter data including voltage, current, power factor and frequency on each phase in three phases system. Secondary data calculated to find voltage and current THD and finally to evaluate the loss of money due to power loss as the result of harmonic and unbalance load. Investigation indicated that the building has not met the IEEE 512-2014 standard for Total Harmonic Distortion. National electricity company, PLN (Perusahaan Listrik Negara) as Government Company, has made regulation about tariff and standard. Electricity tariff in Indonesia has been divided into categories based on user, commercial, social, or housing. Based on this tariff, loss of cost was calculated. Cost due to electricity loss in the building was not high since the building has good electricity installation as green building. Total Harmonic distortion reduction was recommended using single tune order 5 filter.
\end{abstract}

Keywords: Total Harmonic Distortion, Green Building, Single Tune Filter, Energy Efficiency, Power System Analysis

\section{Introduction}

Power quality is a concept in electrical power system concerning the conditions of three parameters: frequency, voltage and current, in the system. Those parameters need to meet a standard that reveals the quality of an electrical power system. When the standard values of the parameter has not been met, they would cause disturbance in the power supply and could be hazardous. High quality of voltage and current could be seen as a smooth sinusoidal waveform [1].

Harmonics is basically an interference to the frequency in the power line system, that has certain ratio to the base frequency; one half, one third, one quarter and so on [2]. In short, it is the presence of waveform in the sinusoidal fundament waveform (Fig. 1 and Fig. 2) either in voltage or current waveform and said to be in odd order, three, five, seven and so on. Harmonics caused loses and imbalance in distribution system, transformer heat that will reduce the life span of the electrical device used [3]. Apart from that, power loss would impact on the high electricity tariff and cost [4] [5]. This research was aimed at analyzing the harmonics effect by the use of low energy devices in the building and the impact on economic aspect.

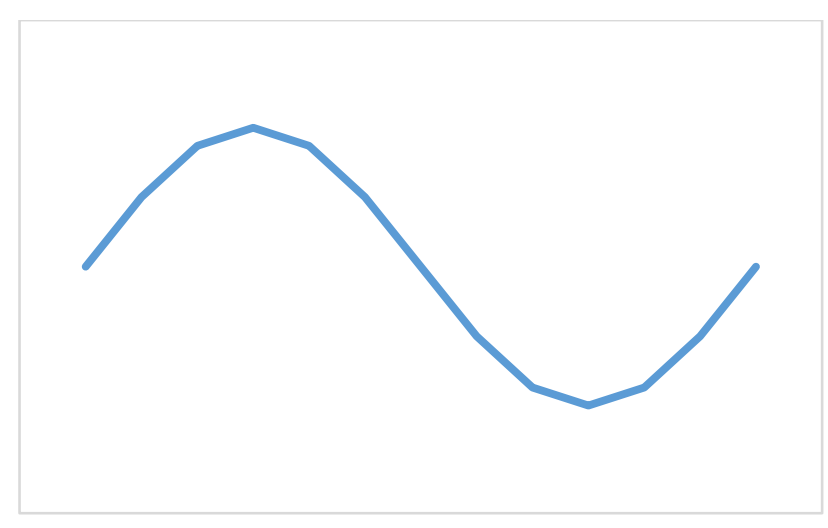

Fig. 1. Base waveform 


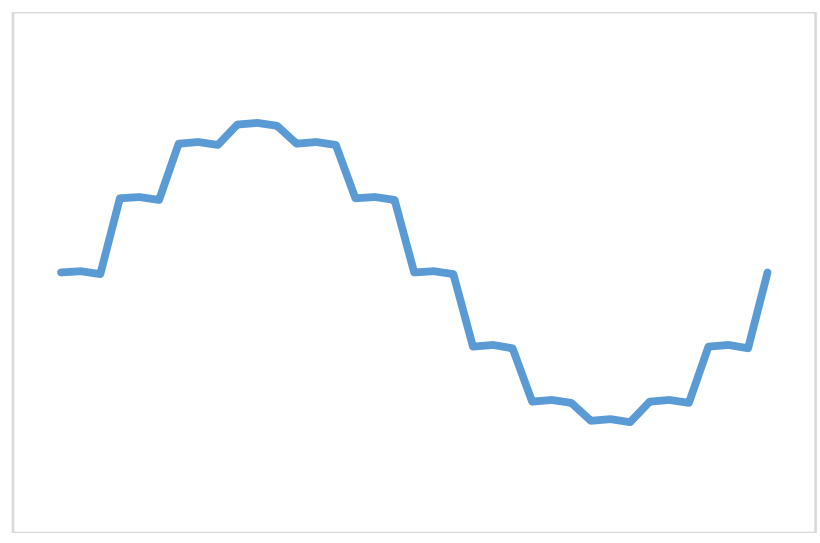

Fig. 2. Waveform with harmonics (lower).

Harmonics occurred in voltage can be demonstrated using the following equation:

$$
U h(\%)=100 \frac{U h}{U 1}
$$

While harmonics in current;

$$
i h(\%)=100 \frac{I h}{I 1}
$$

Mostly concern about harmonics is the Total Harmonics Distortion (THD), concerning both current and voltage. THD depicts the ratio between all harmonics component and the value of fundamental signal.

$$
\mathrm{THD}_{\mathrm{F}}=\frac{\sqrt{V 2^{2}+V 3^{2}+V 3^{2}+\cdots}}{V 1}
$$

IEEE Standard Association has established recommendation for harmonic control in IEEE Std 519-2014. This standard recommended several practices to avoid losses or to reduce interference between electrical devices. This standard also demonstrated instruments compliances, and also recommended limits for harmonic values as follows [6]:

TABLE I

Voltage Distortion LiMiTs (SOURCE IEEE STD 519-2014)

\begin{tabular}{ccc}
\hline Bus voltage V at PCC & $\begin{array}{c}\text { Individual } \\
\text { harmonic } \\
(\%)\end{array}$ & $\begin{array}{c}\text { Total harmonic } \\
\text { distortion THD (\%) }\end{array}$ \\
\hline $\mathrm{V} \leq 1.0 \mathrm{kV}$ & 5.0 & 8.0 \\
$1 \mathrm{kV}<\mathrm{V} \leq 69 \mathrm{kV}$ & 3.0 & 5.0 \\
$69 \mathrm{kV}<\mathrm{V} \leq 161 \mathrm{kV}$ & 1.5 & 2.5 \\
$161 \mathrm{kV}<\mathrm{V}$ & 1.0 & $1.5 \mathrm{a}$ \\
\hline
\end{tabular}

\begin{tabular}{|c|c|c|c|c|c|c|}
\hline $\operatorname{Max}$ & ium & $m c$ & curt & dist & on $i$ & rcent \\
\hline \multicolumn{7}{|c|}{ Individual harmonic order (odd harmonics) } \\
\hline $\begin{array}{c}\text { IsCl } \\
\mathrm{I}_{\mathrm{L}}\end{array}$ & $\begin{array}{c}3 \leq \\
\mathrm{h} \\
<11\end{array}$ & $\begin{array}{c}11 \leq \mathrm{h} \\
<1\end{array}$ & $\begin{array}{c}17 \leq h \\
<23\end{array}$ & $\begin{array}{c}23 \leq \mathrm{h} \\
<35\end{array}$ & $\begin{array}{c}35 \leq \mathrm{h} \\
\leq 50\end{array}$ & TDD \\
\hline$<20$ & $4.0 \%$ & $2.0 \%$ & $1.5 \%$ & $0.6 \%$ & $0.3 \%$ & $5.0 \%$ \\
\hline $\begin{array}{c}20- \\
50\end{array}$ & $7.0 \%$ & $3.5 \%$ & $2.5 \%$ & $1.0 \%$ & $0.5 \%$ & $8.0 \%$ \\
\hline $\begin{array}{l}50- \\
100\end{array}$ & $10.0 \%$ & $4.5 \%$ & $4.0 \%$ & $1.5 \%$ & $0.7 \%$ & $12.0 \%$ \\
\hline $\begin{array}{l}100- \\
1000\end{array}$ & $12.0 \%$ & $5.5 \%$ & $5.0 \%$ & $2.0 \%$ & $1.0 \%$ & $15.0 \%$ \\
\hline
\end{tabular}

TABLE II

SPECIFICATIONS AdOPTED FOR THE SiMUlated INVERTER

Electrical system classifies power into three categories ie; active power $(\mathrm{P})$, reactive power $(\mathrm{Q})$ and apparent power $(\mathrm{S})$, while power itself is the product of voltage and current (Fig. 3). Using mathematical vector, apparent power is calculated as the product of active power and reactive power [7].

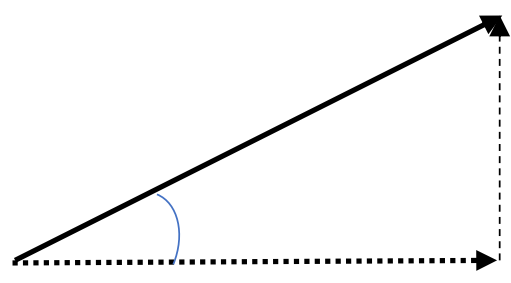

Fig. 3. Power Triangle

$$
\begin{aligned}
& P=V \cdot I \cdot \cos \varphi \\
& Q=V \times I \times \sin \varphi \\
& S=\sqrt{ } P 2+Q 2
\end{aligned}
$$

Where:

$\varphi=$ phase angle $(\mathrm{Rad} / \mathrm{deg})$

$V=$ Voltage (Volt)

$I=$ Current (Ampere)

\section{I.1. Power Factor}

Power factor (Pf) is the cosine of angle $(\varphi)$ between $\mathrm{S}$ and $\mathrm{P}$ theoretically power factor can be calculated using the following equation:

$$
\begin{aligned}
& \text { Pf }=\frac{P}{S} \\
& \text { Pf }=\frac{V I \cos \varphi}{V I} \\
& \text { Pf }=\cos \varphi
\end{aligned}
$$


Indonesian State Electricity Company (Perusahaan Listrik Negara, PLN) has established power factor minimum 0.85 , fine will be applied for any building that has power factor less than 0.85 . Low power factor is due to inductive loads since current phase is $90^{\circ}$ lag to voltage phase. Electrical devices that could reduce power factor, for example, are induction motor, ballast lamp, welding machine etc. [8].

\section{I.2. Unbalance Load}

Electrical load has to be balance in a three-phase system (Fig. 4) [9]. Three phase electrical system is said to be balance when:

- Current and Voltage vector on each phase has the same magnitude;

- Each vector of current and voltage has $120^{\circ}$ angle. Whilst unbalance load happened when [10];

- Vector magnitude of each voltage and current are the same, however the angle are not $120^{\circ}$;

- Each vector of current and voltage has $120^{\circ}$ angle, however the magnitude are different;

- Each magnitude are not the same and angle are not $120^{\circ}$.

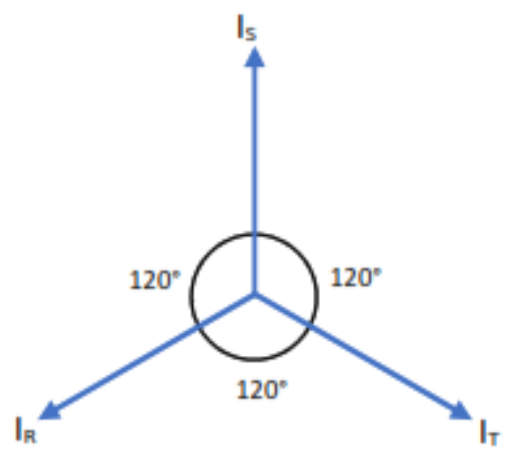

Fig. 4. Balance load vectors

Unbalance loads cause the product of the vectors does not equal to 0 , resulting in the flow of current in Neutral (ground) line. Average current I in unbalance load could be calculated as follows:

$$
I=\frac{I S+I R+I T}{3}
$$

where,

$$
\begin{aligned}
& \text { If } I_{R}=a \times I \text { then: } a=\frac{I R}{I} \\
& \text { If } I_{S}=b \times I \text { then: } a=\frac{I S}{I} \\
& \text { If } I_{T}=b \times I \text { then: } a=\frac{I T}{I}
\end{aligned}
$$

Therefore,

Unbalance $=\frac{\{|a-1|+|b-1|+|c-1|\}}{3} \times 100 \%$

\section{I.3. Unbalance Load Harmonic Effects}

There are numerous effects caused by harmonics either for supply side or user side. Other than damage or disturbance in electricity system, harmonics also cause significant economic effect [11]. Common damage or disturbance that raised due to harmonics is heat in transformer [12]. The heat is caused by Eddy current (Eddy current losses) that reduce the lifetime of the device [13]. The following cases are found due to harmonic distortion [14]:

- Capacitor damage due to harmonic resonance

- Heating in transformer due to harmonic and density flux caused by Eddy current.

- Current flow in neutral line

- Circuit breaker failure

- Vibration on electrical panel caused by high frequency resonance

- Harmonic cause torque resistance in KWH meter resulted in error measurement.

Several researches indicated quite significant loss of electrical power resulted in the increase of annual cost [15]. An ETAP simulation was also done to evaluate transformer performance due to harmonic, indicated the decrease of transformer capacity [16]. Research as in [17] evaluated the relation between harmonic affect and economic loss and concluded that the cost had been increasing significantly for both supplier and user. A research in Australia indicated that the highest contribution of economic loss on consumer's side was harmonic in electrical power system [18]. An optimization using artificial intelligence method was also been investigated to reduce loss and improve voltage profile [19].

\section{Methodology}

Higher education institution is required to give action and put more effort on sustainability measures, this involves every sector in campus life. Universitas Muhammadiyah Yogyakarta recently built a new building for admission process. The building has been designed as green building involving water recycling process, usage of special tinted glass to reduce heat, low emission and low energy lamps and air conditioners. LED lamps and inverter technology for air conditioner could reduce energy usage significantly, however they also induced harmonics as a result of non-linear load [20]. 
During this research, observation was done in a full week to measure several parameters. Primary data were observed and recorded within one hour interval for 24 hours in seven days. The parameters were as follow:

- Current (RMS)

- Voltage (RMS)

- Total Harmonic Distortion (current)

- Total Harmonic Distortion (voltage)

- Frequency

- Power Factor

- Active power

- Reactive power

- Apparent power

- Harmonic current

- Harmonic voltage

Whilst the following data were required as secondary data:

- Electricity tariffs

- Annual/monthly electricity cost

- Transformer specification (in building)

- Cable specification (in building)

Data recorded was then calculated to depict the minimum and maximum fluctuation for each parameter, apart from that average was also calculated. Average date would describe the real condition of the system, while minimum and maximum indicated the behavior of the system to predict error and system failure. Analysis were done using special software on the observed primary data, while secondary data were used to make enhanced analysis and calculation. Analysis data and calculation would indicate the power loss, applied filter for $\mathrm{X}_{\mathrm{C}}$ and $\mathrm{X}_{\mathrm{L}}$, and economic feasibility study for improvement investment.

\section{Result and Analysis}

Admission building was a new building intended as 'GREEN BUILDING' in Universitas Muhammadiyah Yogyakarta. The $2000 \mathrm{~m}^{2}$, twostories building was built in 2017 and was in use since 2018, consisted of administration room, offices, server and computer room, archive and exam rooms.

Admission building was supplied by three phase distribution transformers, built in 1997. Primary voltage was rated $20 \mathrm{kV}$ with rated frequency $50 \mathrm{hz}$, nominal current $36.08 \mathrm{~A}$. On the secondary side, output rated was $400 \mathrm{~V}$, nominal current $1804.22 \mathrm{~A}$ and impedance $5.5 \%$. Based on those data, short circuit current $\left(\mathrm{I}_{\mathrm{SC}}\right)$ calculation was as follow:

$$
\begin{aligned}
\mathrm{I}_{\mathrm{SC}} & =\frac{S k V A \times 100}{\sqrt{3} \times k V \times Z \%} \\
\mathrm{I}_{\mathrm{SC}} & =\frac{1250 \times 100}{\sqrt{3} \times 0.4 \times 5.5} \\
\mathrm{I}_{\mathrm{SC}} & =32808.4 \mathrm{~A}
\end{aligned}
$$

Then to calculate current load:

$$
\begin{gathered}
\mathrm{I}_{\mathrm{L}}=\frac{S}{\sqrt{3} \times V} \\
\mathrm{I}_{\mathrm{L}}=\frac{1250000}{\sqrt{3} \times 400} \\
\mathrm{I}_{\mathrm{L}}=1804.21 \mathrm{~A}
\end{gathered}
$$

Therefore, distortion current ratio can be calculated:

$$
\frac{I S C}{I L}=\frac{32808.4}{I L 1804.21}=18.81
$$

Thus, based on the distortion current ratio, maximum total harmonic ratio is $5.0 \%$

\section{III.1. Measurement Result}

\section{1)Frequency Measurement}

was done for 24 hours with 1-hour interval data from 15/03/2019 to 21/032019. Figure 4 indicated that highest frequency recorded (Fmax) was $50.33 \mathrm{~Hz}$, lowest frequency was $49.87 \mathrm{~Hz}$ and average frequency was $50.1 \mathrm{~Hz}$ (Fig. 5)

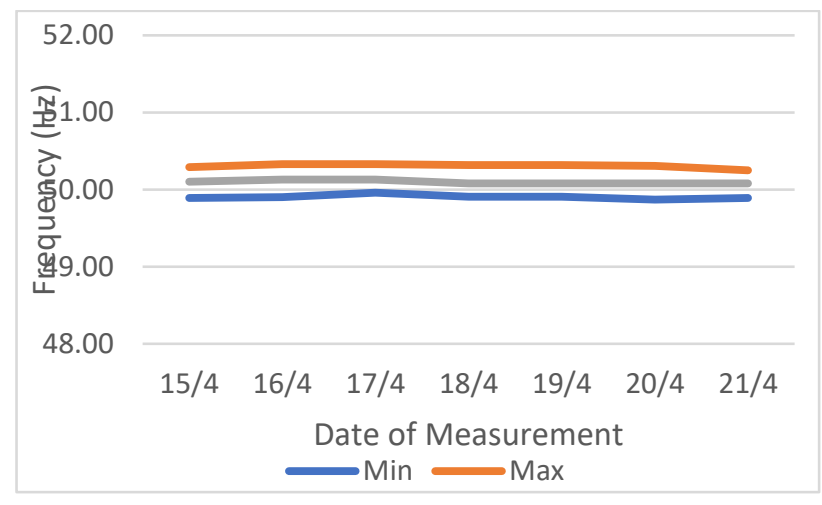

Fig. 5. Frequency fluctuation

Based on measurement, frequency was found within the Indonesian standard range between 49.5 $\mathrm{Hz}$ to $50.5 \mathrm{~Hz}$, thus no problem was found.

\section{2) Voltage Measurement}

Voltage measurement was also done in 24 hours with 1 hour interval. Fig. 6 indicated the highest and lowest voltage recorded for each phase. This was done to observe system failure, where voltage was out of standard range. Average voltage for each phase was recorded the same way and demonstrated in Fig. 7. 


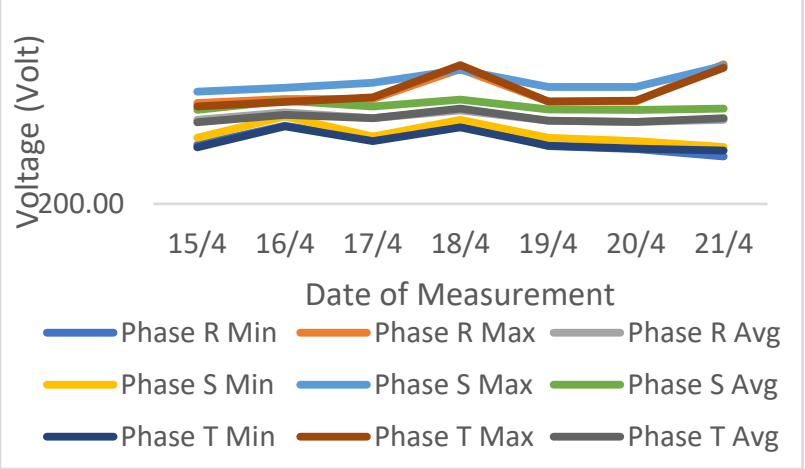

Fig. 6. Voltage Profile

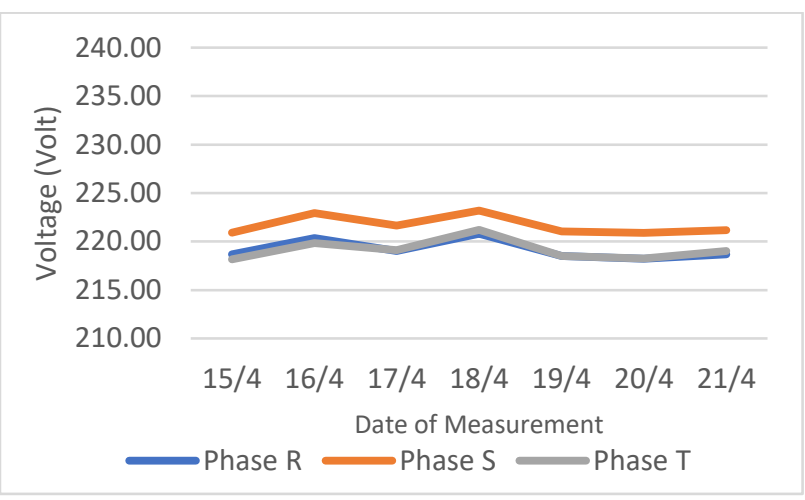

Fig. 7. Average Voltage

Based on Fig. 6, the highest voltage for phase $\mathrm{R}$ was $231.06 \mathrm{~V}$, lowest $210.54 \mathrm{~V}$ and average was $219.187 \mathrm{~V}$, For phase S voltage; highest $230.72 \mathrm{~V}$, lowest $212.65 \mathrm{~V}$ average $221.68 \mathrm{~V}$, and for phase $\mathrm{T}$ voltage; highest $230.86 \mathrm{~V}$, lowest 211.86 and average 219.16. Voltage rating in the building was within standard range i.e., $198 \mathrm{~V}-231 \mathrm{~V}$.

\section{3) Current Measurement}

Current measurement was done in 24 hours with 1 hour interval, shown in Fig. 8 and Fig. 9.

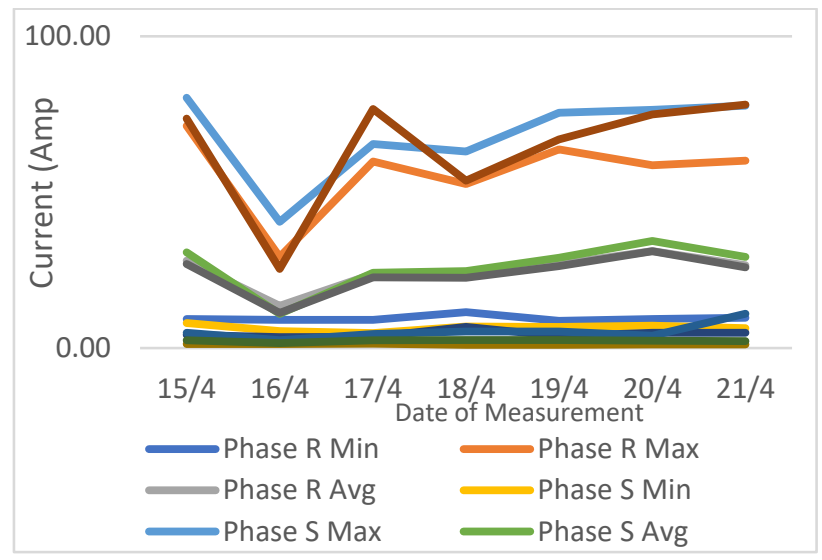

Fig. 8. Current Profile

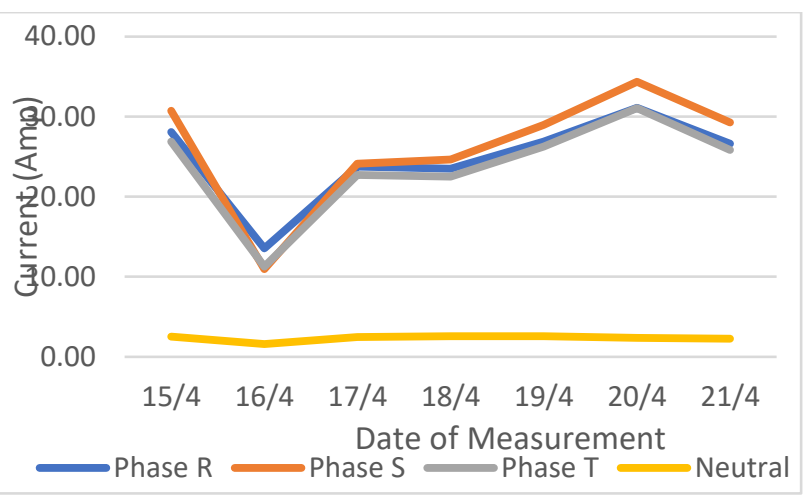

Fig. 9. Average Current

Based on hourly data, current drop indicated between 15:00 - 17:00, whilst almost constant current rate indicated in the evening until 07:00, the increasing current occurred during office hour started rom around 08:00. Lowest current recorded was 8.74 A, highest was 71.27 with average 24.79 A for phase R. Phase S current indicated lowest was 4.81A, highest $80.30 \mathrm{~A}$ and average 26.15A. Meanwhile phase T indicated lowest current was $3.52 \mathrm{~A}$, highest 78.09 A with average 23.80 A. Current was also recorded in neutral line at average of $2.34 \mathrm{~A}$ with highest recorded was $11.02 \mathrm{~A}$ and lowest $1.04 \mathrm{~A}$.

Ideally, current flowing through each phase should be the same, however measurement indicated different result. Average current flowing through phase $\mathrm{S}$ was the highest among others. Therefore, as also measured, current differences between phases resulted in current flow through neutral line that would cause power losses and reduce transformer lifetime. Current flowing through neutral line indicated system error/failure that caused power loss.

\section{4)Apparent Power Profile}

Apparent power profile indicated in Fig. 10 and Fig. 11.

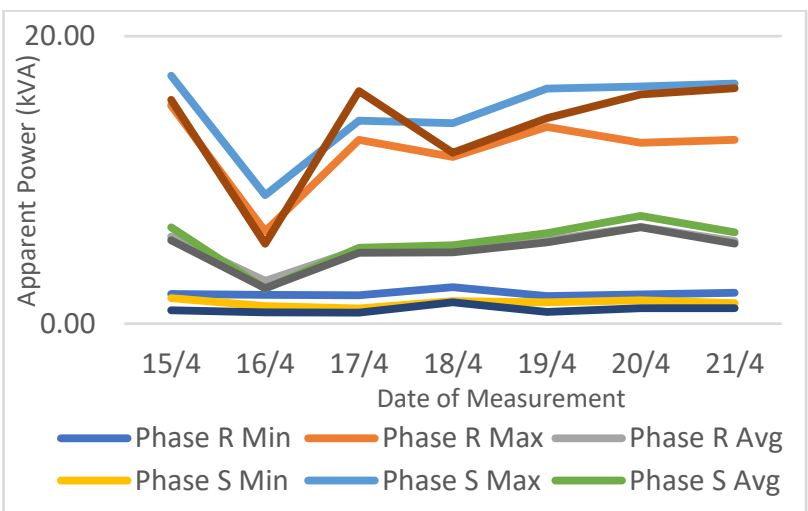

Fig. 10. Apparent Power Profile 


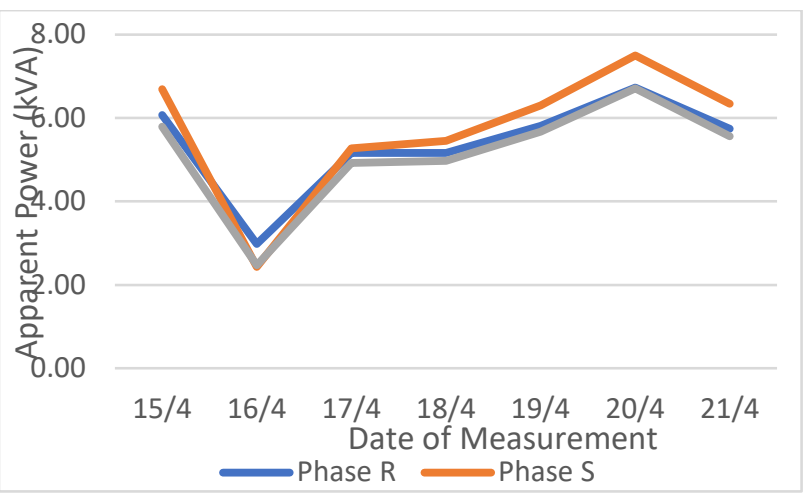

Fig. 11. Average Apparent Power

As the case for current measurement, constant apparent power measured after working hours. Apparent power for phase $\mathrm{R}$ indicated $15.18 \mathrm{kVA}$ at the highest, 1,92 at the lowest and average at 5.38 $\mathrm{kVA}$. While for phase $\mathrm{S}$, highest was $17.25 \mathrm{kVA}$, lowest $1.06 \mathrm{kVA}$ and average were 5.71k VA. For phase $\mathrm{T}$, highest was $16.38 \mathrm{kVA}$, lowest was 0.77 $\mathrm{kVA}$ and average were $5.16 \mathrm{kVA}$. Apparent power difference between phase $\mathrm{R}$ and phase $\mathrm{S}$ calculated was $0.33 \mathrm{kVA}$ and between phase $\mathrm{S}$ and phase $\mathrm{T}$ was $0.56 \mathrm{kVA}$. Apparent power of each phases affected by current and voltage in the system.

\section{5)Active Power Profile}

Profile of active power in the system demonstrated in Fig. 12 and Fig. 13 below.

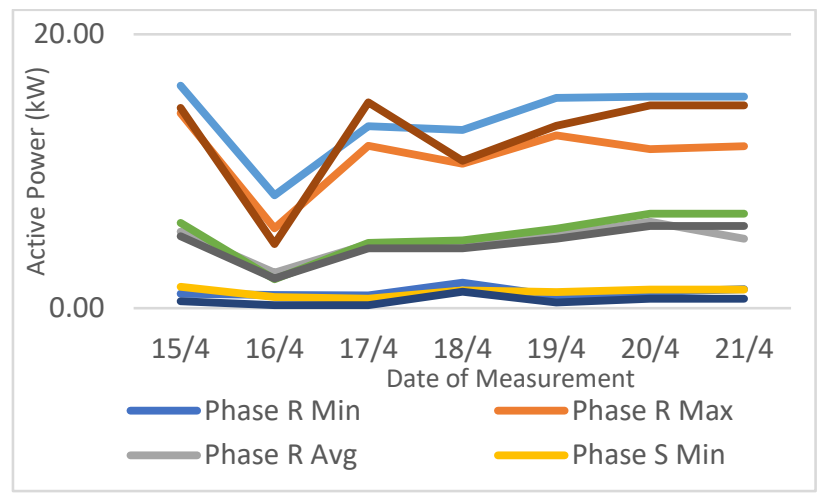

Fig. 12. Active Power Profile

Based on hourly analysis, active power on phase $S$ and $\mathrm{T}$ increased between 17:00 to 23:00. During working hours active power in each phase increased. Phase R highest active power indicated $14.24 \mathrm{~kW}$, lowest $0.9 \mathrm{~kW}$ and average $4.89 \mathrm{~kW}$. Phase $\mathrm{S}$ indicated highest active power $16.25 \mathrm{~kW}$, lowest $0.69 \mathrm{~kW}$ and average $5.38 \mathrm{~kW}$. Phase T indicated highest active power $15.03 \mathrm{~kW}$, lowest $0.22 \mathrm{~kW}$ and average $4.75 \mathrm{~kW}$.

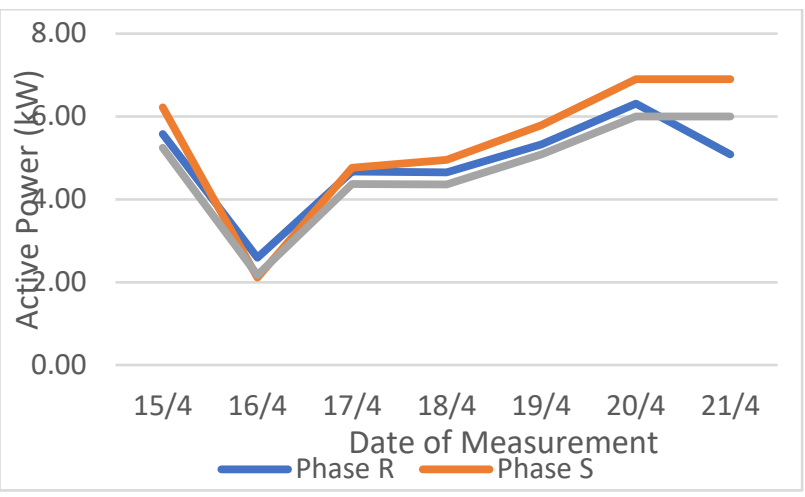

Fig. 13. Average Active Power

Average active power on phase $\mathrm{S}$ was highest compared to phase $\mathrm{R}$ and $\mathrm{T}$. Active power difference between phase $\mathrm{S}$ and $\mathrm{R}$ was $0.49 \mathrm{~kW}$ and between $\mathrm{S}$ and $\mathrm{T}$ was $0.63 \mathrm{~kW}$. Active power was affected by apparent bower and power factor. When active power equal to apparent power, the electrical system was said to be in good condition. In most cases, active power was always lower than apparent power as the result of power factor lower than 1 .

\section{6) Reactive Power Profile}

Reactive power in the system demonstrated in Fig. 14 and Fig. 15.

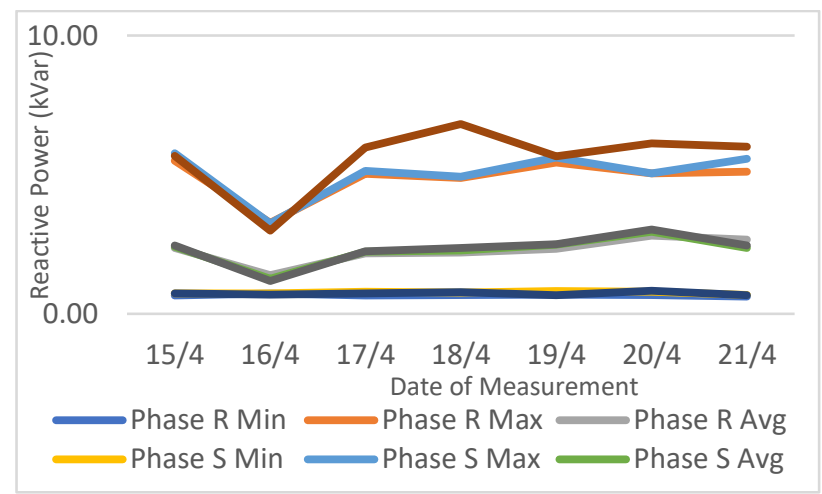

Fig. 14. Reactive Power Profile

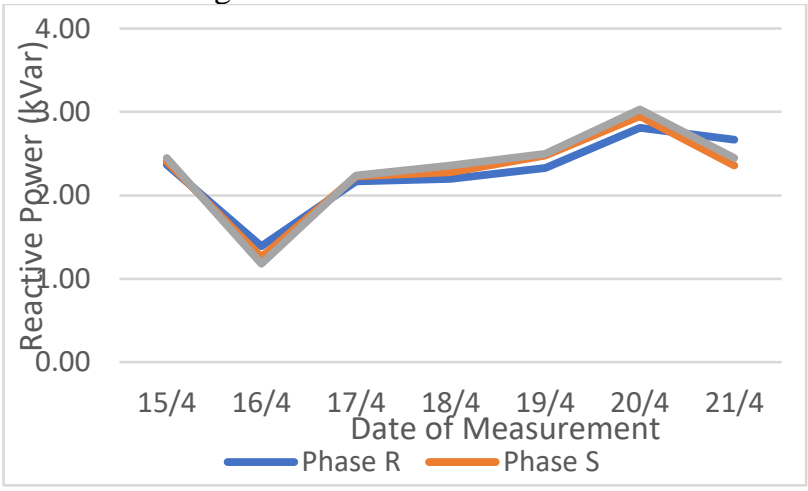

Fig. 15. Average Reactive Power 
Based on Fig. 14 and Fig. 15, highest, lowest, and average reactive power on each phase were as follow. Phase indicated highest at 5.50kVAr, lowest at $0.62 \mathrm{kVAr}$ and average at $4.89 \mathrm{kVAr}$. Phase $\mathrm{S}$ indicated highest at $5.77 \mathrm{kVAr}$, lowest at $0.68 \mathrm{kVAr}$ and average at $5.05 \mathrm{kVAr}$. Phase $\mathrm{T}$ indicated highest at $6.82 \mathrm{kVAr}$, lowest at $0.67 \mathrm{kVAr}$ and average at $6.61 \mathrm{kVAr}$.

Reactive power was affected by capacitive load, in this case was the capacitor bank. Capacitor bank itself was installed to compensate inductive load such as water pump, air conditioner and the likes.

\section{7) Power Factor}

Power factor (Pf) in the system indicated in Fig. 16 and Fig. 17.

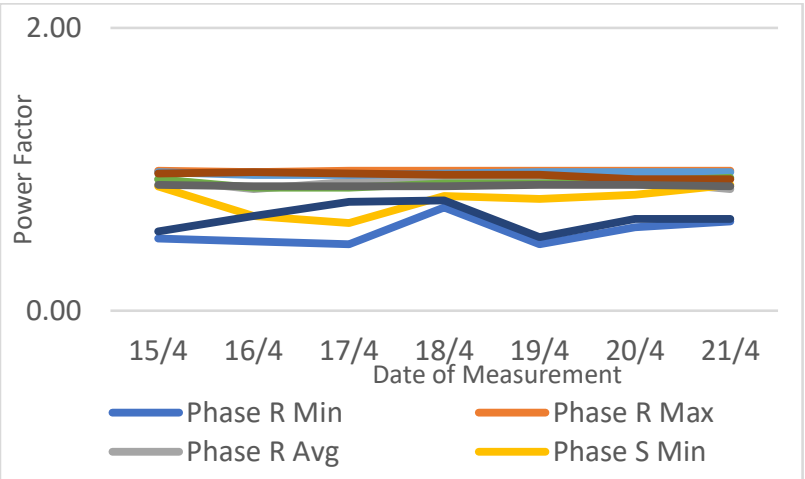

Fig. 16. Power Factor Profile

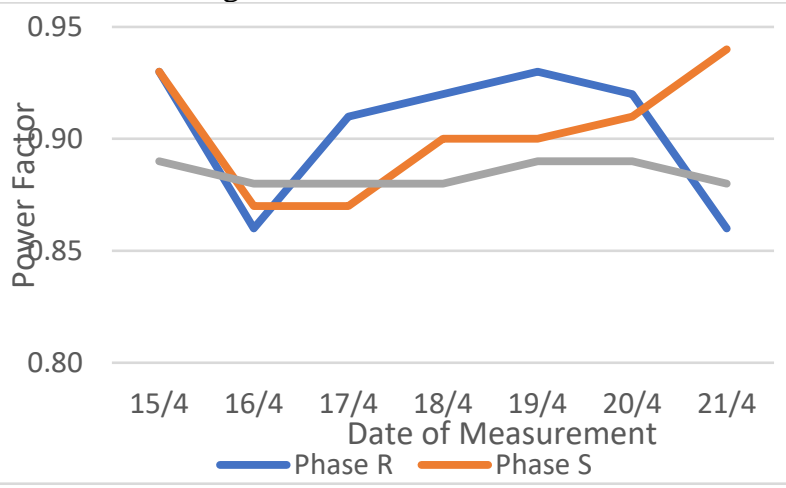

Fig. 17. Average Power Factor

Based on daily analysis, each phase indicated different Pf. Highest Pf recorded for phase R was 0.99 and lowest was 0.47 , while for phase $S$ highest was 0.98 , lowest 0.62 and for phase T highest 0.98 , lowest 0.52, indicated in Fig. 16. Fig. 17 indicated average power factor during observation for phase $\mathrm{R}$ was 0.90 , phase $S$ was 0.90 and phase $\mathrm{T}$ was 0.88 . Daily measurement indicated average $\mathrm{Pf}$ with standard determined by PLN (not lower than 0.85), however during hourly observation Pf dropped to
0.47 at the lowest among the phases. Lowest power factor was out of standard determined by PLN. Low Pf was due to the use of inductive loads. Low Pf also implied on the need of higher power supply that also increase power loss through distribution line.

\section{8) Voltage Total Harmonic Distortion Profile}

Highest, lowest, and average THD demonstrated in Fig. 18 and Fig. 19.

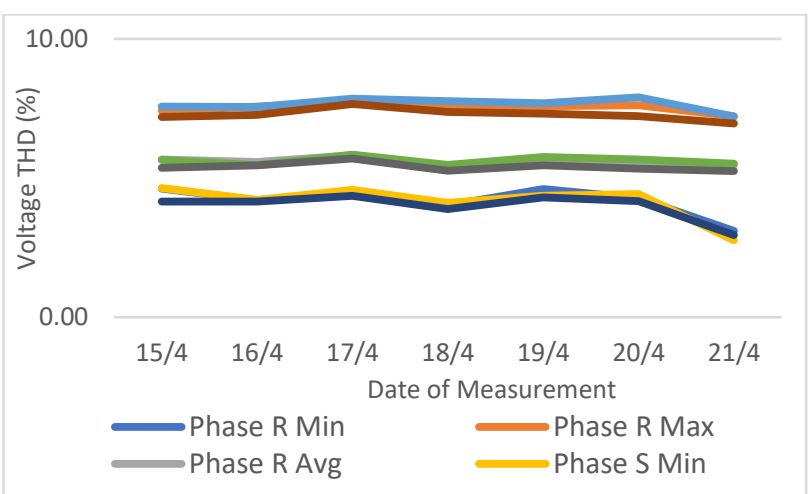

Fig. 18. Voltage THD Profile

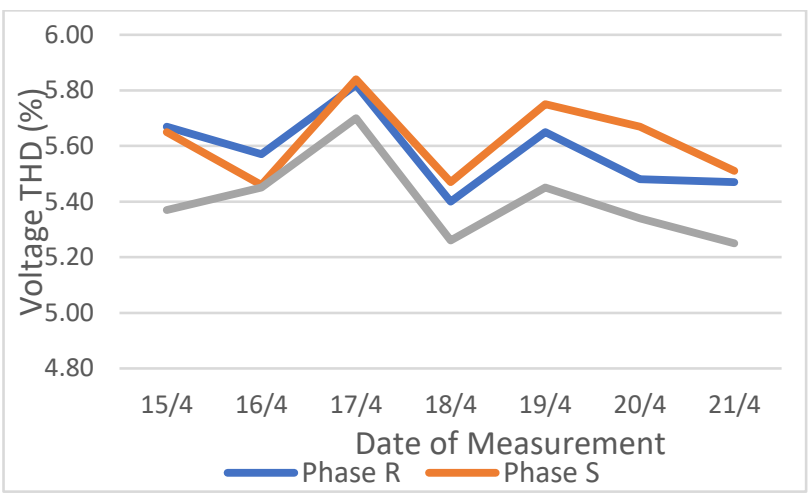

Fig. 19. Average Voltage THD

Voltage THD for each phase was different between phases. Lowest THD for phase R was $3.10 \%$, highest $7.74 \%$ with average of $5.58 \%$. For phase S lowest was $2.76 \%$, highest $7.90 \%$ with average of $5.62 \%$. For phase T, lowest was $2.95 \%$, highest was $7.66 \%$ with average of $5.40 \%$. Those data indicated that voltage THD on electrical power system in the building was out of tolerance according to standard by IEEE 512-2014 for system less than $69 \mathrm{kV}$ with maximum allowed; $5 \%$. Voltage THD was due to the use of non-linear load such as LED lamps, AC with VRF (Variable Refrigerant Flow) etc.

\section{9) Current Total Harmonic Distortion Profile}

Highest, lowest, and average THD demonstrated in Fig. 20 and Fig. 21. 


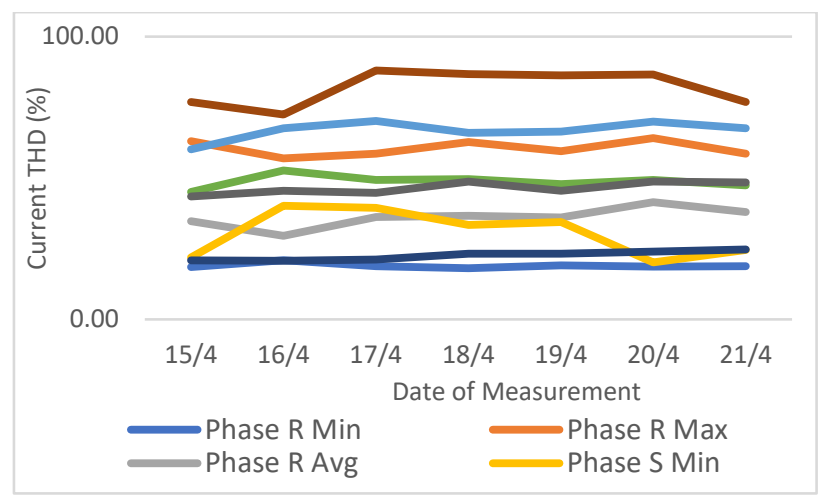

Fig. 20. Current THD Profile

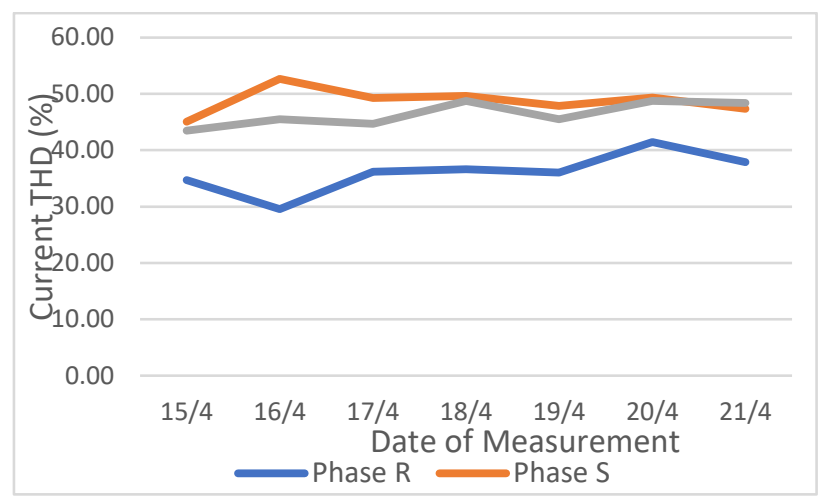

Fig. 21. Average Current THD

Highest, lowest, and average current THD (Fig. 20) for phase $\mathrm{R}$ were, $64.12 \%, 18.45 \%$ and $36.07 \%$ respectively. For phase S, highest was $70.18 \%$, lowest $20.17 \%$ and average was $48.75 \%$. While for phase Thighest was $88.03 \%$, lowest was $20.73 \%$ and average was $46.44 \%$. Those data indicated that current THD for the building was out of tolerance according standard by IEEE 512-2014. Current THD was also the result of the use of non-linear loads.

\section{III.2. Losses Analysis Due to Harmonic and Unbalance Load}

Several conditions and factors in the electrical system contributed to the losses in the system such as:

- Cable/conductor resistance

- Current harmonics in main distribution panel

Resistivity of cable used in the building was 0.193

$\mathrm{Ohm} / \mathrm{km}$ with aperture $95 \mathrm{~mm}^{2}$. Distance between main distribution panel and transformer was $100 \mathrm{~m}$, therefore resistance of the cable was $0.0193 \mathrm{Ohm}$.

Odd order of harmonics was used to calculate loss on each phase and neutral. Harmonic current was distinguished between peak load and non-peak load and was sampled for minimum and maximum measurement. The result is demonstrated in Table III:

TABLE III

LOSSES ON PHASE R, S, T AND NEUTRAL

\begin{tabular}{cccc}
\hline Losses Condition & Phase & Low & High \\
\hline \multirow{3}{*}{ Peak Load Loss (Watt) } & $\mathrm{R}$ & 14.30 & 12.53 \\
& $\mathrm{~S}$ & 9.88 & 10.88 \\
& $\mathrm{~T}$ & 9.32 & 11.06 \\
& $\mathrm{~N}$ & 0.20 & 0.07 \\
Total & 33.70 & 34.53 \\
\hline \multirow{2}{*}{ Non-Peak Load Loss } & $\mathrm{R}$ & 14.30 & 12.53 \\
(Watt) & $\mathrm{S}$ & 9.88 & 10.88 \\
& $\mathrm{~T}$ & 9.32 & 11.06 \\
& $\mathrm{~N}$ & 0.11 & 0.05 \\
& Total & 33.70 & 34.53 \\
\hline
\end{tabular}

\section{III.3. Cost Analysis Due to Harmonic and Unbalance Load}

Indonesia's regulation considers the use of any building and implies to the tariff applied the user. As higher education institution, UMY electricity tariff was considered as social use, therefore the tariff is as follow:

- Peak load (18:00-22:00) : Rp 1.337/kWh

- Non-peak load (23:00-17:00) : Rp 955/kWh

Based on data in Table III, with assumption of 24 workdays and 4 off-days within one month, cost of loss can be calculated as follow:

TABLE IV

Cost of Loss Due to HARMONIC AND UnBALANCE

\begin{tabular}{lcccccc}
\hline & \multicolumn{3}{c}{ Workdays } & \multicolumn{3}{c}{ Off-Days } \\
\hline & Peak & $\begin{array}{l}\text { Non- } \\
\text { Peak }\end{array}$ & Total & Peak & $\begin{array}{c}\text { Non- } \\
\text { Peak }\end{array}$ & Total \\
\hline $\begin{array}{l}\text { Daily } \\
\text { Lost }\end{array}$ & 231 & 1,239 & 1,470 & 225 & 154 & 380 \\
(Rp) & & & & & \\
$\begin{array}{l}\text { Monthly } \\
\text { Lost } \\
\text { (Rp) }\end{array}$ & & & & & \\
Annual & 83,029 & 446,179 & 44,098 & 901 & 617 & 1,518 \\
Lost \\
(Rp)
\end{tabular}

From Table III, total lost due to harmonic and unbalance can be calculated and yielded Rp 547,394. 


\section{III.4. Harmonic Reduction}

Measurement and calculation have indicated that current harmonic was out of tolerance according to IEEE 512-2014. Average current harmonic during full week measurement indicated a day with the highest harmonic at $46.51 \%$ on March 20, 2019. Therefore, current harmonic for each phase on measurement on this day was used to calculate filter for harmonic reduction. Single tuned filter can be used to reduce harmonic for one order only, therefore need to calculate the highest harmonic in each order as indicated in Table IV. The Table IV indicated highest harmonic at order5, therefore harmonic can be reduced using order 5 single tuned filter with frequency of $250 \mathrm{~Hz}$.

TABLE V

HARMONIC ON ORDER 3-11

\begin{tabular}{cccccc}
\hline Phase & Order 3 & Order 5 & Order 7 & Order & Order \\
\hline$R$ & $8.47 \%$ & $30.28 \%$ & $21.36 \%$ & $6.55 \%$ & $9.05 \%$ \\
$S$ & $24.40 \%$ & $31.30 \%$ & $25.20 \%$ & $7.29 \%$ & $7.57 \%$ \\
$T$ & $12.62 \%$ & $37.40 \%$ & $26.87 \%$ & $3.97 \%$ & $8.99 \%$ \\
\hline
\end{tabular}

Single tuned order 5 filter specification can be calculated using voltage $380 \mathrm{~V}$, maximum current (order 5) $19.4 \mathrm{~A}$, yielded resistance equal to $19.58 \mathrm{Ohm}$. Therefore, power rating for of the filter can be calculated as:

$$
\begin{aligned}
& \mathrm{P}=\mathrm{V} \times \mathrm{I} \\
& \mathrm{P}=380 \times 19,4 \\
& \mathrm{P}=7372 \text { Watt }
\end{aligned}
$$

Q factor (filter quality factor) can be calculated, assuming Q:30 (Q between 30-100).

$$
\begin{aligned}
& X_{l}=X_{C}=X_{n} \\
& \mathrm{Q}=\frac{X_{n}}{R} \\
& X_{n}=Q X R \\
& X_{n}=30 X 19.58 \\
& X_{n}=587.4 \Omega
\end{aligned}
$$

Inductor calculated as follow, assuming frequency $245 \mathrm{~Hz}$ (max order 5 frequency $250 \mathrm{~Hz}$ ):

$$
\begin{aligned}
X_{l} & =\omega l \\
\mathrm{~L} & =\frac{X_{l}}{\omega} \\
\mathrm{L} & =\frac{587.4 \Omega}{2 \times 3.14 \times 245} \\
\mathrm{~L} & =0.382 \mathrm{H}
\end{aligned}
$$

Capacitor can be calculated (using the same order 5 frequency):

$$
\begin{aligned}
& X_{C}=\frac{1}{\omega C} \\
& \mathrm{C}=\frac{1}{\omega X_{C}} \\
& \mathrm{C}=\frac{1}{(2 \times 3.14 \times 245) 587,4} \\
& \mathrm{C}=1.106 \times 10^{-6} \mathrm{~F}
\end{aligned}
$$

With the above calculation, single tuned filter that can be used to reduce harmonic was as follow:

- Resistance (R) : $19.58 \Omega$

- Inductance (L) : $0.382 \mathrm{H}$

- Capacitance (C) : $1.106 \times 10^{-6} \mathrm{~F}$

- Impedance $\mathrm{X}_{\mathrm{C}}=\mathrm{X}_{\mathrm{L}}=\mathrm{X}_{\mathrm{n}} \quad: 587.4 \Omega$

\section{Conclusion}

As a green building, Admission Building in Universitas Muhammadiyah Yogyakarta was supposed to fulfill the requirement of low and efficient electrical energy usage. However, observation and measurement involving peak and non-peak hours including workdays and off-days indicated that the building suffered from harmonic distortion. The highest voltage total harmonic distortion reached $7.90 \%$ and highest current total harmonic distortion reached $46.44 \%$ at the average. This harmonic also caused loss of cost approximately Rp 547,394 annually. The cost seemed to be small compared to the total electricity cost, but this calculation only involved one building with relatively small installed power capacity. Higher loss would be very significant when calculation applied to the entire campus area with many buildings and with total installed power capacity of $1,730 \mathrm{kVA}$. Thus, the observation and measurement only depicting less than $5 \%$ of the campus electrical power system.

Total harmonic distortion can be reduced by using single tuned filter with R: $19.58 \mathrm{Ohm}, \mathrm{L}: 0.382 \mathrm{H}, \mathrm{C}$ : $1,106 \times 10^{-6} \mathrm{~F}$ and $\mathrm{X}_{\mathrm{C}}: 587.4 \mathrm{Ohm}$. Comparing cost of filter installation and loss of cost annually, the investment was too high. Admission building indicated relatively small cost of lost since the building has been designed to meet the criteria of green building.

\section{Acknowledgements}

This work was supported by Universitas Muhammadiyah Yogyakarta. 


\section{References}

[1] E. Fuchs and M. Masoum, Power Quality in Power Systems and Electrical Machines, Elsevier, 2015.

[2] A. J. Mehta and K. L. Mokariya, "Harmonics in Power System and it's Mitigation Techniques," in National Symposium on Recent Trends in Electrical Engineering, Gujarat, 2010.

[3] G. A. AJENIKOKO and A. I. OJERINDE, "Effects of Total Harmonic Distortion on Power System Equipmen," Innovative Systems Design and Engineering, vol. 6, no. 5, pp. 114-120, 2015.

[4] T. K. Hariadi, P. J. Prahara, S. B. Lesmana and R. Saidi, "Energy saving technology analysis for commercial, industrial, social, and public sectors to support regional energy policy: Case study in Daerah Istimewa Yogyakarta," International Journal of Applied Engineering Research, vol. 12, no. 22, pp. 11933-11940, 2017.

[5] A. K. Sharma, B. S. Rajpurohit and S. N. Singh, "A review on economics of power quality: Impact, assessment and mitigation," Renewable and Sustainable Energy Reviews, vol. 88, no. 5, pp. 363$372,2018$.

[6] IEEE, 519-2014 - IEEE Recommended Practice and Requirements for Harmonic Control in Electric Power Systems, IEEE, 2014.

[7] N. LaWhite and M. D. Ili' c, "Vector Space Decomposition of Reactive Power for Periodic Nonsinusoidal Signals," IEEE TRANSACTIONS ON CIRCUITS AND SYSTEMS-I: FUNDAMENTAL THEORY AND APPLICATIONS, vol. 44, no. 4, pp. 338-346, 1997.

[8] S. W. Blume, ELECTRIC POWER SYSTEM BASICS For the Nonelectrical Professional, WILEYINTERSCIENCE, 2007.

[9] D. Das, Electrical Power System, New Delhi: New Age International (P) Ltd., Publisher, 2006.

[10] M. H. Albadi, A. S. A. AlHinai, A. H. Al-Badi, M. S. AlRiyami and R. S. AlAbri, "Unbalance in Power Systems Case Study," in IEEE International Conference on Industrial Technology (ICIT), Seville Spain, 2015.

[11] R. Pinyol , HARMONICS: CAUSES, EFFECTS AND MINIMIZATION, Salicru, 2015.

[12] C. Kocatepe, R. Yumurtacı, O. Arıkan, M. Baysal, B. Kekezoğlu, A. Bozkurt and C. F. Kumru, "Harmonic Effects of Power System Loads: An Experimental Study," in Power Quality Issues, London, Intechopen, 2013, pp. 175-200.

[13] C. PAN, L. KONG, Z. LI , Q. ZHENG and Z. WANG, "Analysis Based on Improved Method for Transformer Harmonic Losses," in International Conference on Future Energy, Environment, and Materials, Hong Kong, 2012.

[14] M. Y. Asrami, S. M. B. Sadat and E. Samadaei, "Harmonic Study for MDF Industries: A Case Study," in IEEE Applied Power Electronics Colloquium (IAPEC), Johor Bahru, 2011.
[15] M. Ashour, K. Youssef and S. E. Sobki, "THE COST OF HARMONIC LOSSES AND MITIGATIONS IN DISTRIBUTION SYSTEMS," in 18th International Conference on Electricity Distribution, Turin, 2005.

[16] N. Nasrul and F. Firmansyah, "Harmonics Impact a Rising Due to Loading and Solution ETAP Using the Distribution Substation Transformer $160 \mathrm{kVA}$ at Education and Training Unit PT PLN," International Journal on Advance Science Engineering Information Technology, vol. 5, no. 6, pp. 469-474, 2015.

[17] Z. Lin, X. Zhang, X. Mao, Y. Zhan, X. Peng and B. Zhang, "Economic evaluation of harmonic cost," in IEEE 8th International Power Electronics and Motion Control Conference (IPEMC-ECCE Asia), Hefei, 2016.

[18] S. T. Elphick, P. Ciufo, V. W. Smith and S. Perera, "Summary of the economic impacts of power quality on consumers," in Power Engineering Conference (AUPEC), Wolonggong, 2015.

[19] R. SYAHPUTRA, S. SURIPTO, S. SOEDIBYO and I. SOESANTI, "APPLICATION OF CLONAL SELECTION IMMUNE SYSTEM METHOD FOR OPTIMIZATION OF DISTRIBUTION NETWORK," Journal of Theoretical and Applied Information Technology, vol. 95, no. 15, pp. 36043612, 2015.

[20] M. A. Stošović, M. Dimitrijević, S. Bojanić, O. NietoTaladriz and V. Litovski, "CHARACTERIZATION OF NONLINEAR LOADSIN POWER DISTRIBUTIONGRID," Electronics and Energetics, vol. 29, no. 2, pp. 159-175, 2016.

\section{Authors' information}

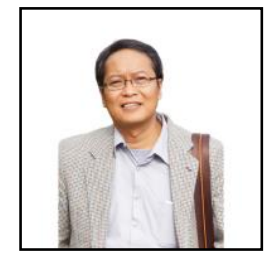

Tony K. Hariadi obtained his B. Eng in Electrical Engineering from Universitas Gajah Mada, Indonesia in 1993. His Master study was done at 2013 at the Electrical Engineering, Universitas Gadjah Mada, Indonesia. He currently is a lecture in department of electrical engineering, Universitas Muhammadiyah Yogyakarta.

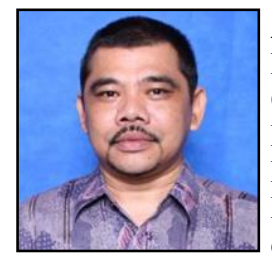

Agus Jamal obtained his B. Eng in Electrical Engineering from Universitas Gadjah Mada, Indonesia in 1994. His Master study was done at 2010 at the Electrical Engineering, Universitas Gadjah Mada, Indonesia. He currently is a lecture in department of electrical engineering, Universitas Muhammadiyah Yogyakarta.

Nurohman Fadilah obtained his B. Eng in Electrical Engineering from Universitas Muhammadiyah Yogyakarta, Indonesia in 2019. 


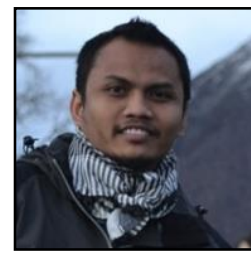

Faaris Mujaahid obtained his B. Eng in

Electrical Engineering from Saxion

University of Applied Sciences Netherlands

in 2010. His Master study was done at 2016

at the Electrical Engineering, University of

Southampton, England. He currently is a

engineering, Universitas Muhammadiyah Yogyakarta. 